\title{
Democracy and Development in Southeast Asia: A Critical Comparison
}

\author{
M.Faishal Aminuddin ${ }^{1}$, Joko Purnomo ${ }^{2}$ \\ ${ }^{1}$ Faculty of Social and Political Sciences, Universitas Brawijaya, Indonesia, mfaishal@ub.ac.id \\ ${ }^{2}$ Faculty of Social and Political Sciences, Universitas Brawijaya, purnomo@ub.ac.id
}

\begin{abstract}
There is an intriguing debate relating to the relationship of economic development to democratization. Southeast Asia region is one of the fast-growing economic development, and it also has a long journey to democratization. The result, however, is ambiguous regarding the internal dynamic of this region that hinders the possibility to have consolidated democracy. However, an achievement in economic development might facilitate political development. This paper will provide a critical note about the relationship between development and the political regime in the SEA region. This paper also analyzes the reason why there is no significant change regarding political regime within this region even though some countries are continuing to have positive achievements in democratization. Also, autocracy and the authoritarian regime still survive in this region. This paper assesses the progress of social and economic development and its impacts on domestic politics, then, attempts to explain the process of political transformation in the SEA region to understand the causes that hinder the spreading of democratization. Qualitative method will be used to analyze data and provide conclusion of this study.
\end{abstract}

Keywords: democratization, development, political transformation, SEA countries

\begin{abstract}
ABSTRAK
Terdapat perdebatan menarik terkait hubungan pembangunan ekonomi dengan demokratisasi. Wilayah Asia Tenggara adalah salah satu kawasan dengan perkembangan ekonomi yang tumbuh cepat, dan juga memiliki perjalanan panjang menuju demokratisasi. Hasilnya, menunjukkan ambiguitas dalam dinamika internal yang berpotensi tingkat konsolidasi demokrasi. Kendatipun, pencapaian dalam pembangunan ekonomi mungkin memfasilitasi pembangunan politik. Artikel ini akan memberikan catatan penting tentang hubungan antara pembangunan ekonomi dan bekerjanya rezim politik di kawasan Asia Tenggara. Kami menganalisis alasan mengapa tidak banyak perubahan yang signifikan dari rezim politik di wilayah ini meskipun beberapa negara terus memiliki prestasi positif dalam demokratisasi. Sebaliknya, rezim otokrasi dan otoriter justru masih terlihat bisa bertahan. Artikel ini menilai kemajuan pembangunan sosial dan ekonomi dan dampaknya terhadap politik dalam negeri, kemudian, berupaya untuk menjelaskan proses transformasi politik untuk memahami penyebab yang menghambat penyebaran demokratisasi. Studi ini menggunakan metode kualitatif dengan melakukan analisa data-data kuantitatif untuk membangun konklusi hasil studi.
\end{abstract}

Kata Kunci: demokratisasi, pembangunan, transformasi politik, negara Asia Tenggara

\section{Introduction}

In the late 1990s, the political regimes of Southeast Asia in the post-Cold War were still dominated by autocracy. It was only 27 years later that the democratic regime began to wriggle. There are problems, however, concerning stability and quality of the democracy. In this region, the remaining types of autocracy vary from a robust government supported by the military to the full power of the monarchy. Likewise, in their struggle to become democratic countries, each country has a peculiar history and internal dynamics. In a sense, the mechanism of causality for change is 
more controlled by the trigger and driving factors in itself rather than by dynamic changes in neighboring countries within the region.

The outburst of Reformasi movement in Indonesia in 1998 brought no direct impact on political openness in other countries. Myanmar, for instance, only started its first general election in 2014 after a long decade underwent the military junta. The democratic stability held by the Philippines after the falling down of Marcos in the early of the 1980s began to despair in the emergence of a populist regime lead by Rodrigo Duterte as the elected president. The fall of UMNO and Najib Razak in Malaysia in 2018 returned the power to a senior politician, i.e. Mahathir Muhammad, to be re-elected as the prime minister. The sagas in Myanmar and Malaysia happened closely. Thinking of what has occurred in Indonesia, geographic proximity did not guarantee the emergence of a mutually inspiring event.

Considering economic achievement, finance, and market stability, Singapore, Brunei, and Malaysia are more flourished but those factors cannot give rise to democracy to breed and uprising. The illustration is as follow. For a long time, there has been a growing belief that the political awareness of citizens would largely determine democracy. However, different from the growth of democracy in the West, where economic achievement and political stability thought to have a direct impact on triggering the establishment of democracy, countries in SEA region tend to be more autocratic although their economic growth might be categorized as the Asian Miracle. The obvious break was that the "ersatz capitalism" went to bankruptcy as the economic foundations that supported it were discovered fragile and weak, such an occasion that led to the economic crisis in 1996-1997. In Indonesia, the crisis caused the fall of the Suharto's regime that had been in power for around 32 years. Nonetheless, other neighboring countries in SEA could carry out their economic recovery program without producing a similar political turmoil.
This article aims to provide critical explanations of the relationship between democracy and development. We are elaborating the empirical facts about the performance of socio-economic development in SEA countries, then link them with the interpretation of democratization. We limited the analysis by focusing on data sequence starting from 1990 till 2017. In so doing, we aimed at explaining the performance of political regime and its fluctuations. Also, we incorporated the analysis of socioeconomic variables to examine whether there is a relationship or not between socio-economic development and democratization, on purpose to address factors that tended to be overlooked in the assumptions and conclusions derived from the previous studies on democratization in this region. This study argues that economic development does not always breed democracy. The development of healthy political system especially to maintain sustain and high level political participation is a necessary task to be done for consolidated democracy. A significant social and economic progress be perceived by its citizen are important aspects for maintaining political participation.

\section{Literature Reviews}

In the study of 147 countries in the period 1960-2005, it categorized 63 countries as those countries in democratic transitions. It reveals that the process of democratization grew in many countries that consisted of welleducated people. Economic development and education were determinant factors for the intensity of democratic reforms and how fast democratization occurred ${ }^{1}$. Other important studies, in contrast, argued that whether development has a significant impact on democracy or still debatable depends on how

\footnotetext{
${ }^{1}$ Elias Papaioannou and Gregorios Siourounis. "Democratisation and growth." The Economic Journal 118, no. 532 (2008): 1520-1551.
} 
to measure $\mathrm{it}^{2}$. In the context of Southeast Asia, scholars also found a different conclusion. The colonial policies that treated Chinese migrant merchants in Southeast Asia in hostility had produced segregated and different identities that strengthened the capitalists to maintain and support authoritarian regimes ${ }^{3}$. This inheritance of colonial policy is so-called as the Asian-style of democracy, a view which combines the democratic political institutions with their unique cultural forms in each country ${ }^{4}$. Above all, the massive pressures of modernity and enormous economic changing have transformed various conditions in society, especially a shifting from agrarian to industrial and service sectors ${ }^{5}$. Similarly, although a handful of ruling elite classes who enjoy economic achievements, in its growth it is also followed by the development in some degrees of forces in civil society. The influence of economic development on democratization also benefits the communal elites, even with varying degrees, to be able to get political autonomy through a long process of political development ${ }^{6}$.

\footnotetext{
${ }^{2}$ Adam, R. Przeworski, Michael E. Alvarez, Jose Antonio Cheibub, and Fernando

Limongi. Democracy and development: political institutions and well-being in the world, 1950-1990.

Vol. 3. Cambridge University Press, 2000.

Doorenspleet, Renske. "Democracy and Development." In Rethinking the Value of Democracy, pp. 201-236. Palgrave Macmillan, Cham, 2019.

${ }^{3}$ John T. Sidel, "Social origins of dictatorship and democracy revisited: colonial state and Chinese immigrant in the making of modern Southeast Asia." Comparative Politics 40, no. 2 (2008): 127147.

${ }^{4}$ Clark Neher, Democracy and development in Southeast Asia: the winds of change. Routledge, 2018.

${ }^{5}$ William Case, Politics in Southeast Asia: democracy or less. Routledge, 2013.

${ }^{6}$ Dan Slater, "Revolutions, crackdowns, and quiescence: Communal elites and democratic mobilization in Southeast Asia." American Journal of Sociology 115, no. 1 (2009): 203-254.
}

Democratization studies in the SEA region required comparative studies by concentrating on deciphering the characteristics of the regime, i.e. the role of the military, political parties, and state apparatuses in supporting the non-democratic regime. Also, it requires to provide an explanation about existing anomalies as well as gives an adequate assessment of the causal mechanism upon which a new hypothesis is less widely conveyed. For example, the paradox of democratization which showed an increase in political participation but was followed by the closure of the political contestation channel. It resulted in the paralysis of organizational capacity in mobilizing collective actors in various socio-economic cleavages ${ }^{7}$. To be captured in a specific objective of democracy and development, there exist two main perspectives. First, the perspective that concludes development can cause democratization, such as the case of the Philippines and Thailand. Second, a perspective that considers that development does not encourage the birth of democracy or further democratization ${ }^{8}$. In this research, we positioned to provide a critical explanation in finding the connectivity between democracy and development in the region while identifying the factors that hinder democratization which, ideally, have positive correlation with development, both economic and political.

\section{Theory and Method}

In choosing the analytical framework, we reviewed some important theorizations about democracy and development studies. There two main ideas. In part, classical

\footnotetext{
${ }^{7}$ Kanishka Jayasuriya and Garry Rodan. "Beyond hybrid regimes: more participation, less contestation in Southeast

Asia." Democratization 14, no. 5 (2007): 773-794.

${ }^{8}$ Anek Laothamatas, ed. Democratization in

Southeast and East Asia. Vol. 76. Institute of

Southeast Asian Studies, 1997.
} 
development theory tends to pay attention to economic factors that trigger the establishment of democracy. In another part, theories of democracy tend to explain various changes and system dynamics and political culture as the main factors that sustain the success of economic development. In both mainstream, institutional influences and electoral competition have been considered to be dominant and crucial factor in the development of democracy. Nevertheless, in its development, democracy does not concern only about elections as its foundation although it is considered as the key generator in carrying out democratic agendas ${ }^{9}$. From the perspective of Western democracy, there are strong indications that high socio-economic development can give guarantees for a country to be more democratic. In other words, economic prosperity is a prerequisite for the growth and development of democracy ${ }^{10}$.

Significant cross countries studies in the relationship between democracy and development show that there is little evidence on the positive causal relationship between them ${ }^{11}$. The relation might be subtler. In theoretical perspective, economic development often refers to the process of modernization in society, such as industrialization that brings in impact upon urbanization and the increasing level of education from those involved in worker associations. The impacts create a complexity of social relations that contribute to

\footnotetext{
9 Joseph Schumpeter,. "Creative destruction." Capitalism, socialism and democracy 825 (1942): 82-85. Carothers, Thomas. " Thomas Carothers. The end of the transition paradigm." Journal of democracy 13, no. 1 (2002): 5-21.

${ }^{10}$ Seymour Martin Lipset. "Political man: The social bases of politics." (1959). Almond Gabriel, A., and Sidney Verba. "The civic culture: Political attitudes and democracy in five nations." Princeton: Princeton University (1963).

${ }^{11}$ Larry, Sirowy and Alex Inkeles. "The effects of democracy on economic growth and inequality: A review." Studies in Comparative International Development 25, no. 1 (1990): 126-157.
}

deterioration of authoritarianism. Study cases in Portugal, South Korea, and Greece show that development is successful in fighting dictatorial regimes. In another way around, the results of testing that validate the impact of the political regime upon the share of investment in GNP, the growth rate of capital stock, and the labor market, for instance, show that political regimes do not have a direct effect on economic development, but only to political stability. More intriguingly, substantial evidence shows that economic development causes democracy to survive ${ }^{12}$.

\section{I}

\footnotetext{
${ }^{12}$ Seymour Martin Lipset and Jason M. Lakin. The democratic century. Vol. 9. University of Oklahoma Press, 2004. Przeworski, Adam. "Democracy and economic development." Mansfield \& R. Sisson (Eds.), The evolution of political knowledge. democracy, autonomy, and conflict in comparative and international politics (2004): 300-324. Cheibub, José A., and James R. Vreeland. "Economic Development, Democratization and Democracy." In 3rd International Conference on Democracy as Idea and Practice, University of Oslo. 2012.
} 
Table 1. Polity IV data on Southeast Asia's political regime.

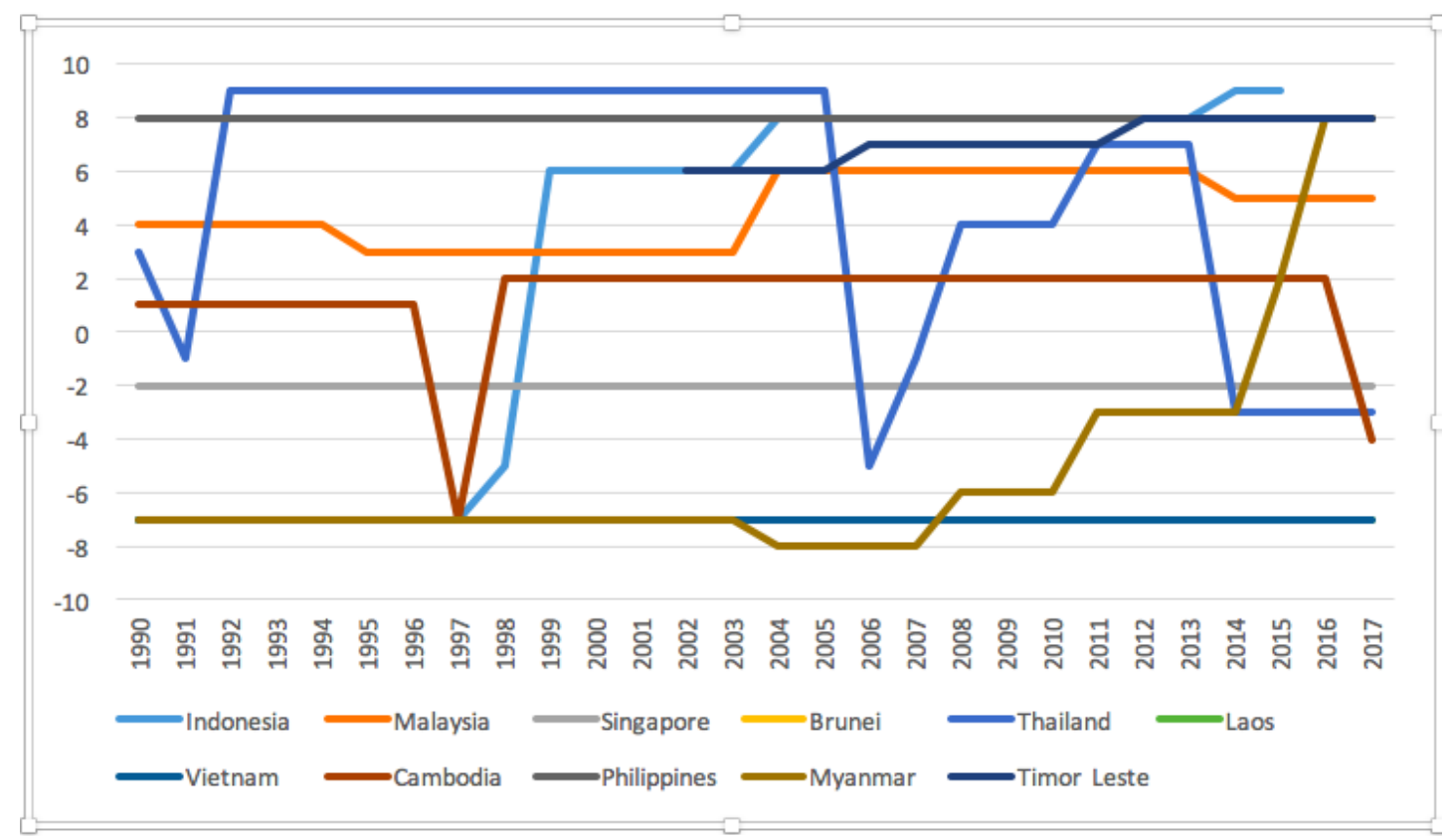

Source: POLITY IV

In this article, we analyze data which mainly taken from Polity IV to generate the map of political regimes in South East Asia between the period of 1990-2017. The period is presupposed to give a picture of the regime fluctuation during the post-Cold War. Countries in Southeast Asia during that period show complicated political development where some countries fell into autocratic regime regardless its level of economic performances. It differs with European countries' experience where positive economic performance correlates with the establishment of democratization.

We aim at portraying the changing characteristics of the political regime from authoritarianism to anocracy to democracy, upon which the dynamics of progress and setbacks could provide specific clues about what is happening in each country. We can derive the entire profile of the political regime of countries in the region except for Brunei Darussalam. However, in a variable of analysis, we will include this country with the assumption that Brunei is a part of autocracy.

We examine three hypotheses: 1) human development influences the fluctuations and dynamics of political regimes. 2) economic development has a positive relationship to democratization. 3) the higher economic income of citizens has resulted in more stable democratization will be. In order to testify this hypothesis, we will analyze the data from the UNDP report which consists of: The Human Development Index (HDI), Economics Index (EI), and Income Index (II). This study is limited to describing and analyzing quantitative data with qualitative descriptions. We do not conduct quantitative analysis with statistical methods to conclude the correlation aspects of the above variables.

From the data compiled from Polity IV (see Table 1), we can group the stability of the political regime in Southeast Asia from 19902017 into three types: first, countries that have political regime stability; both autocracy 
(Vietnam), anocracy (Singapore) and democracy (Philippines); second, countries that have extreme fluctuations in political regimes change such as Thailand; third, countries that move dynamically such as Indonesia. In the first type, we recognized Vietnam as the country within the scope of static Autocracy since 1990-2017. After the collapse of the eastern bloc in the post-cold war, the country is still solid with the socialist state model that adheres to a single party system. Meanwhile, Myanmar, which since 1990-2007 entered the autocracy category, began to build its acceleration towards democratization. In just seven years (20082015), this country recorded significant improvements and could be included into the category of democracy in 2016.

Singapore has a stable closed-anocracy regime. The stability is backboned by entirely controlled of parliamentary government which had effectively in limiting the political participation and narrowing the space for political ideology in electoral contestation whereas the Philippines enjoys a relatively stable democratic life for a long time. Although, it can be called substantially "fragile" because of extreme patronage politics which hinders deepening democracy and the construction of civilian social capital ${ }^{13}$.

In the second type, Thailand showed the extremity of open-anocracy then suddenly fell into autocracy. Even though, it did not take a longer time to return to democracy. The military continually held a strong domination to the political process amidst the conditions of a centralized and non-institutionalized political party ${ }^{14}$. As a result, the military coup became a

\footnotetext{
${ }^{13}$ Garry Rodan and Kanishka Jayasuriya. "The technocratic politics of administrative participation: case studies of Singapore and

Vietnam." Democratization 14, no. 5 (2007): 795-

815. James Putzel. "Survival of an imperfect

democracy in the Philippines." Democratization 6, no. 1 (1999): 198-223.

${ }^{14}$ Paul Chambers and Aurel Croissant, eds. Democracy under Stress: Civil-Military
}

dangerous scourge that caused extreme fluctuations in their democracy. Meanwhile, in the post-1998, Indonesia entered democracy. The trend continues to improve, although it still has not touched the full democracy scale. Political competition still contains many problems because of the remaining weaknesses of political parties and parliaments ${ }^{15}$.

The dynamics of the political regime as showed by Polity IV data indicate that South East Asia has interesting phenomena to explore. In addition to the factors that cause differences amongst countries in the region such as political competition, democratic institutionalization issues, and other aspects, relations of civil to military are common to be studied. Other factors, nevertheless, are rare to explore, such as economic aspects, human development, and political participation.

Relations in South and Southeast Asia. Silkworm Books, 2010.

${ }^{15}$ Edward Aspinall and Marcus Mietzner, eds. Problems of democratisation in Indonesia: elections, institutions and society. Institute of Southeast Asian Studies, 2010. 
Table 2: HDI \& Economic Index
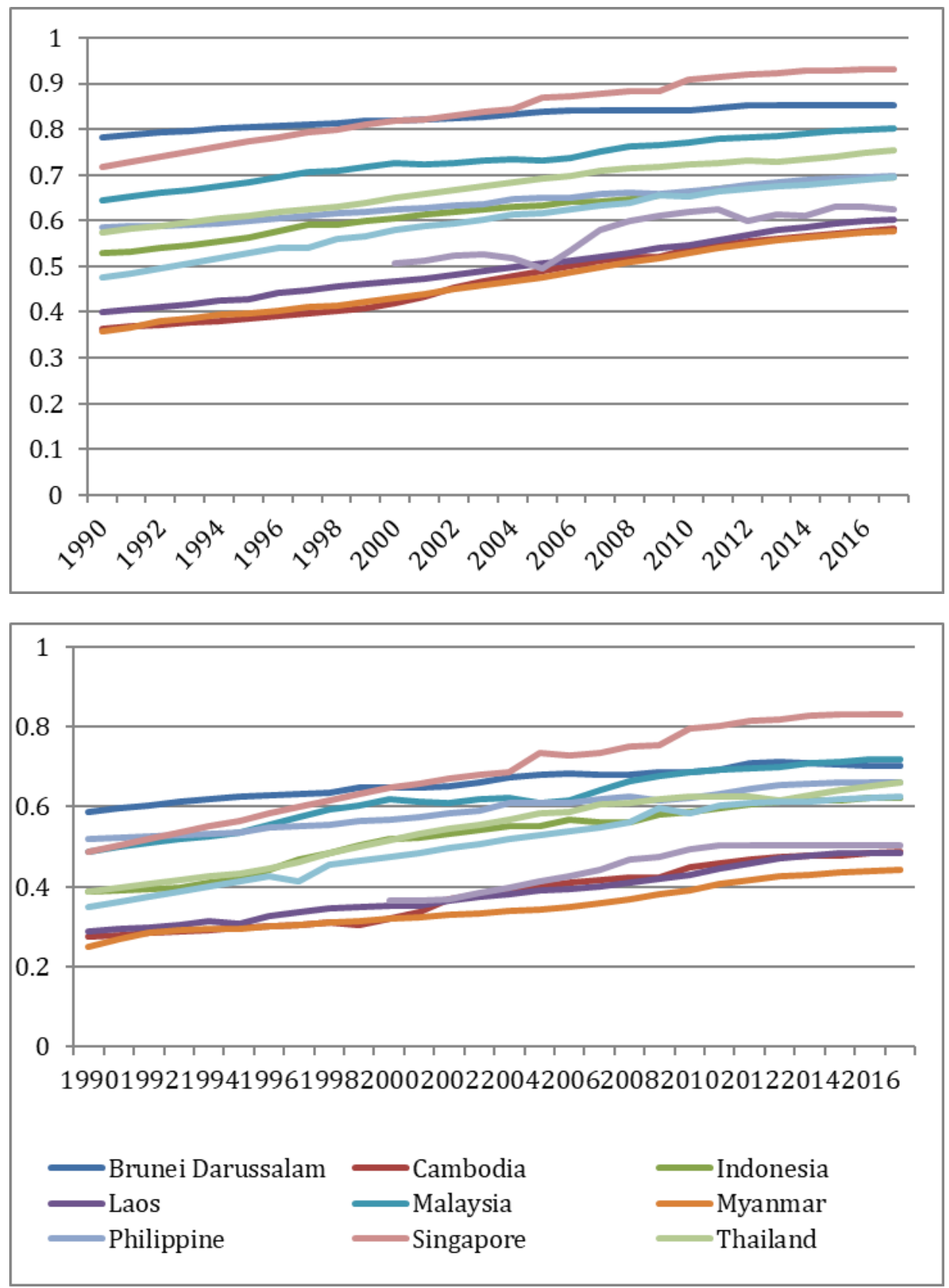

Source: UNDP, 2017

Socio-Economic and Human Development: General Trend

This region obtains a vast growth of economic development. It is estimated that during 1971-1989 this region overshadowed the world's average growth rate by $2.72 \%$. Also, there has been a significant increase in the number of free trade agreements, from 3 in
2000 to 61 in $2010^{16}$. More open economic policy and the deepening integration with

${ }^{16}$ Kanta Marwah, and Akbar Tavakoli. "The effect of foreign capital and imports on economic growth: Further evidence from four Asian countries (19701998)." Journal of Asian Economics 15, no. 2 (2004): 399-413. Antoinette Raquiza. State Structure, Policy Formation, and Economic Development in Southeast Asia: The Political 
international trade significantly foster the economic achievement. The success story in economic achievement is also followed by the significant increase in the HDI for all countries. Economic progress facilitates an increase in life expectancy, level of education, and per capita income. From UNDP report (Table 2) Singapore improved the index from 0.718 (1990) to 0.932 (2016), Brunei Darussalam 0.782 (1990) to 0.853 (2016), and Malaysia 0.642 (1990) to 0.802 (2016)) achieve the highest level of HDI respectively. During 1990- 2017, these three countries were continuing to accelerate its HDI performance in comparison to the rest of other countries. The superior level of these three countries was estimated to be difficult to be defeated by other countries.

Singapore, Indonesia, and Thailand are three countries that gained the fastest acceleration on its HDI level's improvement during 1990- 2017 period. Significant acceleration of Indonesia and Thailand on HDI level is a fascinating trend, and it gives a positive signal on a narrowing gap regarding the quality level of life. Other countries such as Vietnam, Laos, Cambodia, Myanmar, however, were still in modest progress on HDI level during the same period.

The positive trend in economic development provides a strong foundation for the continuing progress on HDI level. Economic liberalization and integration to international trade have facilitated sustain economic growth. Within IMF data (2016), each country in the SEA shows significant progress on economic performance since the late 1990s onward. After the financial crisis in the late 1990s, SEA has shown significant improvement in economic growth and economic crisis's resilience. Ten years after the 1998s economic crisis, this region recovers and maintains its growth in average at $9 \%$ annually until 2012. From that period, this region always enjoys a higher level of economic growth comparing to the world's economic growth even at the time of economic crisis occurs. IMF data (2016) also showed a significant increase the countries capability to handle economic crises, as it was shown in 2008-2009's and 2012-2013's economic crises.

The income level depicted also the impressive trend in economic growth. During the period of 1990 till 2017, most the countries performed a significant improvement regarding per capita income. A particular policy such as more open to Foreign Direct Investment (FDI) and also import policy has contributed to this positive economic performance. There is, however, an intriguing trend to narrow the gap of per capita income's performance between countries. This trend indicates that two highest per capita income's countries in 1990, i.e. Brunei Darussalam and Singapore, present the lowest pace of acceleration during 1990-2017 in comparison to the rest of the countries. Hence, the distance in income level is getting shorter.

The narrowing gap of per capita income's performance also provides the fact that there is a moderate decline in inequality between countries. Even though Brunei Darussalam and Singapore are still experiencing the higher level of per capita income's performance, countries such as Malaysia, Thailand, and Indonesia are chasing the economic performance of both Brunei and Singapore. 
Table 3. Average Growth (net Gini Index)

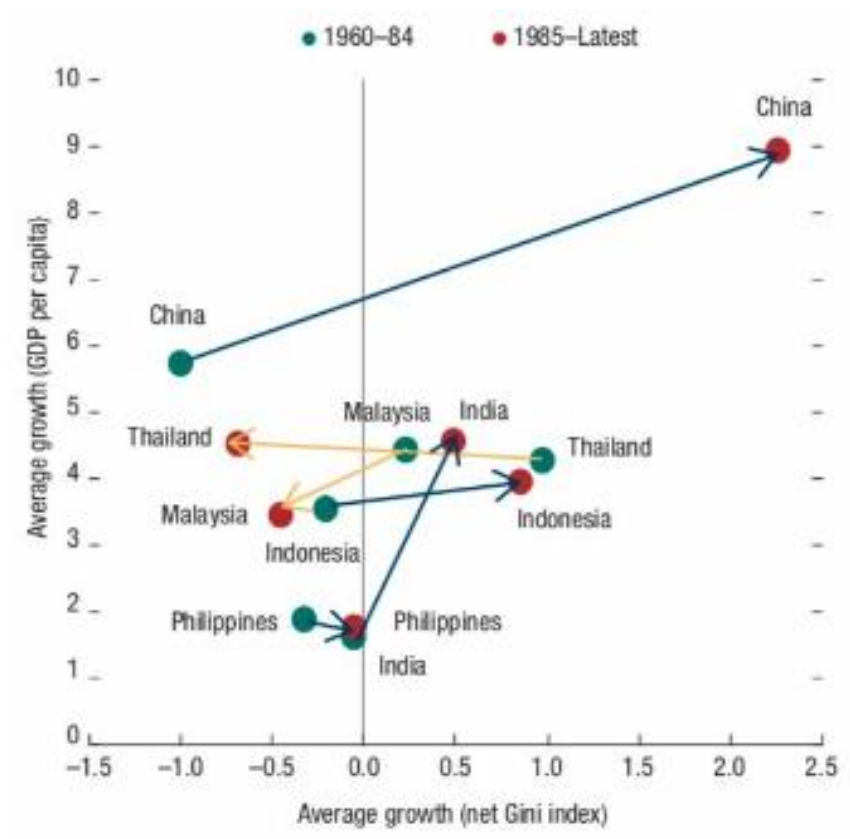

Source: regional economic outlook: Asia and Pacific, IMF, 2016

Interestingly, from 2012 onwards, the two countries are in the steady stage of income's performance. It is providing an explanation on the narrowing gap on per capita income's performance in the region. Unfortunately, Thailand and Indonesia that have significant acceleration on per capita income have difficulties to tackle inequality within a country. Learning from the data published by IMF (2016), the Gini index of those two countries is still high if not the worst (Table 3 ).

The rise of inequality in Indonesia and Thailand were alarming. As the continuing rise in per capita income in that two countries generates inequality, it is a problem that can trigger economic and political tension. To some degrees, it implicates that those in authority could not provide a proper economic policy that manages the results of development to be equally redistributed to its people. It differs from what happens in Malaysia and Philippine where the rise of economic development is also followed by the low level of inequality (Table 3 ). The specific economic policy established by Malaysia and Philippine contributes to the inequality decline (IMF, 2016). From this comparison, there emerges critical questions, why do countries in the region that have kept inequality in low level gain political stability? and why do they not necessarily need to transform their autocratic or authoritarian regimes? Hypothetically, a proper economic policy that accelerates growth at the robust level and specific polity to reduce inequality plays a great role in such a situation. Interestingly, those countries with a higher income's performance are under autocracy regimes. It is evident in the experience of Brunei, Singapore, Malaysia. Three countries with good incomes are still in autocratic during the 30 -year periods. Strong performance in sustainable economic progress does not necessarily escalate the democracy. Moreover, the political situation in these countries during the 30 years are relatively stable. It confirms the argument that economic development does not always breed political transformation into a more democratic political system. The authority does not necessarily need to change its autocratic regime when they 
can deliver high and sustain economic progress.

An exception, however, in Indonesia and Thailand, the increase in income level does not have any correlation with the continuing trend of the autocratic style of leadership. During the 30 years, two countries tend to be more democratic. Democratization has successfully institutionalized resulted in competitive elections, even though in recent year illiberal democracy appears. In both countries, economic progress is accompanied by democratization. It seems that moderate achievement, not the substantial achievement, in economic development provides potential ground for democratization. Cambodia, Laos, Vietnam, and Myanmar (CLVM) are four countries that are still in the different level of economic achievement if they are compared to Brunei, Singapore, Malaysia, Thailand, and Indonesia. Even though they are continuing to make positive progress during the 30-year periods, the progress in the economic achievement of CLMV countries is still lacking behind and still considered as LowIncome Countries (IMF Regional Outlook, 2016). The problem that economic progress of CLMV countries is accompanied by an increase in inequality. Consolidated democracy does not emerge in these four countries, and they are continuing the struggle to detach from an authoritarian regime. Hence, there is only a little progress in political transition among them.

The previous elaboration implies three essential messages about social transformations. First, the autocratic regime does not have to make a political transformation into the democratic type of regime as long as they can maintain a significant progress in economic development as in the cases of Brunei and Singapore. Second, political transformation to a democratic regime occurs in a country that has modest progress in economic development as in Indonesia and Thailand. Third, small progress in economic development has little contribution to change authoritarian regime as in Laos, Cambodia, Myanmar, and also Vietnam.

There is a hint that a progress in economic performance cannot be perceived as a central factor to explain political transformation to democracy. Political stability resulted in sustain and steady progress in economic performance is a crucial factor to keep in any regime. They can hold its original type of regime, whether it is autocratic as in Brunei and Singapore or it is authoritarian as in Vietnam and Laos, as long as the economic progress and the government facilitates economic expansion. Good progress on economic development and political stability resulted from proper maintenance in economic life in the region, however, was not necessarily followed by democratic establishment. It is in contrast to some European countries where there are connections between democratization and positive economic achievement (World Bank, 1999). No matter it is, the autocratic or authoritarian regime continues to sustain in some countries.

A dramatic political change in Indonesia in the late 1990s did not trigger other countries in SEA to follow the path of democratization of Indonesia. We argue that the wave of democratization does not take place although economic developments were present. Successful experience in the political transformation to democracy in one country does not trigger other countries to follow. Every country is still in isolation in one another politically, and there is no sign of the demonstration effect within this region. There exists political disconnection continuing to emerge amongst countries and for such a reason economic performance does not provide a significant influence on the political transformation in the whole region of SEA.

In SEA region, three countries that experience a significant escalation of education level during 1990 - 2017 are Singapore, Malaysia, and Indonesia respectively. On the other side, the improvement of index in Brunei, from 0.787 (1990) to 0.853 (2016), Thailand from 0.583 (1990) to 0.0.755 (2016), 
and Laos from (0.400 (1990) to 0. 601 (2016), it is recognized as a moderate increase in education level during the same period (UNDP-HDI Report, 2017). Interestingly, if we compare to the government expenditure on education, the education level does not exclusively correlate with the continuous increase in the amount of government spending in education. Malaysia, Thailand, and Singapore are three countries that already provided significant investment in education but there is a declining trend from 2011 onward. On the other hand, Indonesia, Laos, and Vietnam have an increasing trend from 2011 onward.

Indonesia that continuously increases its government expenditure ( 0.528 in 1990 to 0.694 in 2016) is among the fastest country accelerating in the increase in education level (UNDP-HDI Report 2017). Countries such as Singapore, Malaysia, and Thailand that reduced education expenditure from 2011 onward still keep their improvement in education level until 2017 (UNDP-HDI Report, 2017). From UNDP data on education level, we can conclude that there is a tiny link between the higher education level of a country with the type of political regime. Singapore, Brunei Darussalam, and Malaysia are still in autocratic regime even though their education levels are among the highest level. In contrast, Indonesia and Philippine that level of education is not so high can be considered as a democratic country and far beyond from autocratic regime. With this finding, we can propose a hypothesis that higher education level does always not guarantee the establishment of a democratic regime.

\section{Discussion Note: Identifying Isolative Factors}

Economic development and the process of deepening democracy may have a positive correlation as it shows in the political and economic dynamics in some SEA countries from 1990 to 2017 - some countries that can maintain their good economic performances harvest a positive political development transforming into more democratic countries. Other countries, however, are still trapped on autocratic regimes although the economic developments are robust as Singapore and Brunei Darussalam. In order to understand this situation, a deepening exploration on what happens in domestic politics and economics is heavily needed.

Democracy provides better choices for citizens to participate in accelerating their common prosperity. The impact of democracy on this matter can be known from the changes in various fields; ranging from national macroeconomic structures to the social security system. There is evidence that a democratic regime is capable of reducing infant mortality. It erodes pessimism that democracy does not help much to improve human development.

SEA region has shown that the fluctuations of the political regime are not always positively correlated with the development of democratic politics. Undertaken indicators of HDI, for example, every country has an interest in providing better education and health facilities and infrastructure to its citizens. In this case, HD is the result of the long-term expansion of economic growth in which an increase in HD can be achieved with a growth-oriented and sustainable economic policy. However, there are differences in priority scale. In countries under the dictator or autocracy regime, health services and social security are not the primary. A study presents that there is a relationship between life expectancy and democracy, in case that health policy interventions are prioritized in democratic countries. From the data taken in the period 1980-1990, those developing democratic countries have the highest achievement of HD indicators ${ }^{17}$.

\footnotetext{
${ }^{17}$ Besley, Timothy, and Masayuki Kudamatsu.

"Health and democracy." American economic review 96, no. 2 (2006): 313-318.
} 
Table 4: Political Participation in SEA region

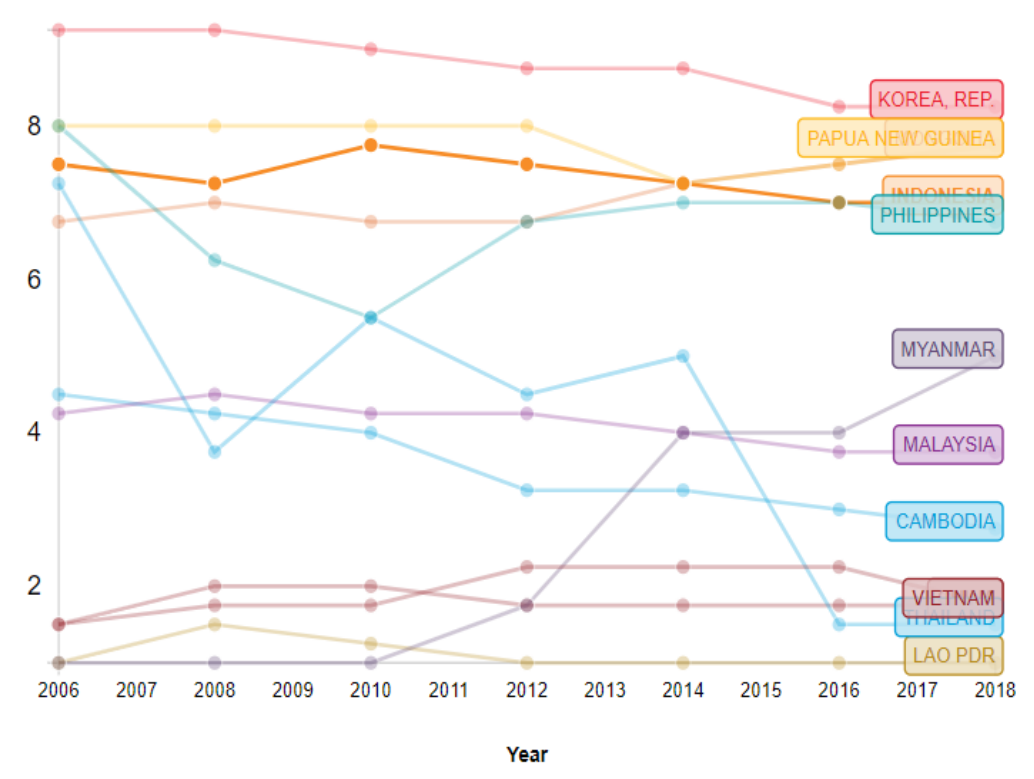

Source: Berstelsmann Transformation Index, 2018

The increasing number of citizens who satisfy with positive achievement of economic and social development could contribute to the deepening democracy. The way the authority fulfills the expectation of its citizen is a significant factor contributing to the change in political regime within the country. As in Singapore and Brunei, the authority still can manage its autocratic regime due to its high and sustained economic and social achievement. The citizen who is economically and socially satisfied does not necessarily need the change of political regime into the more democratic atmosphere. On the other hand, the citizen can trigger the political regime when the authority does not adequately fulfill the economic and social interests. As it can be found in Indonesia and Philippines, the average performance of economic development and social development done by the authority triggers the demand for political change into the more democratic country as it can be expected to enlarge the need of citizen concerning economic and social development.
Hence, the interests of citizen and its view on the authority performances in economic and social development play an essential factor for the explanation of the correlation between economic development and the deepening of democracy. Based on experiences of the SEA countries, the rise of inequality and Gini index of the countries create economic vulnerability that could produce citizen dissatisfaction, and in turns led to the increasing demand for political change. Autocratic and authoritarian regime survives with lower political participation regardless of the degree of level of education, as shown in Singapore, Malaysia, Laos, and Vietnam. We argue that the survival of the non-democratic regime is facilitated by the incidence of the low level of political participation. Considering the data of political participation, we might also confirm that political transformation into more democratic regimes could occur if the political participation is at a high level as the lesson learned from Indonesia and the Philippines. 
There is a declining trend of political participation shown in Vietnam, Thailand, Laos, and Cambodia in recent years (Table 4). If this trend is continuing, then it is hard to expect democracy can breed in this region. The decline of political participation seems to be correlated with the decline of people's trust in the election. The data from Perceptions of Electoral Integrity (2018) show that countries continue with a declining trend on political participation, such as Cambodia, Malaysia, and Thailand, are also undergoing low perception on electoral integrity. Meanwhile, countries such as Indonesia and Philippines that are better in the perception of electoral integrity also have a higher degree of political participation

As each country in SEA region has its internal dynamic and different stages of political, economic and social development, there is a limited collaborative action on fostering democratization within the overall region. Countries that are experiencing the deepening democracy such as Indonesia and Philippines do not stimulate other countries to follow the political development. In this way, democratization happened in one country is resulted from the internal dynamic that is contingent to citizens and their authority. It makes democratization is more likely based on internal dynamic rather than based on regional dynamic.

Political development that relies on internal dynamic is also followed by the discontinuing wave of democratization within this region. Countries such as Singapore and Brunei Darussalam still keep their autocratic regime and do not necessarily have to make conformity with the raise of democratization that happens in other countries. We note that the phenomenon of discontinuing waves of democratization in Southeast Asia is caused by three factors. First, a regional cooperation such as ASEAN does not provide space for reciprocal interventions between countries. It makes every political change in each country to become a single event and does not have a significant impact on other countries as it was ravaged by the 32 years New Order of Indonesia authoritarian rule which severely restricted pro-democracy social movements. The effort of government to ban various prodemocracy forces from open political contestation also appears in Vietnam ${ }^{18}$. In this region, all authoritarian regimes rely on their legitimacy and resilience from their ability to emphasize free and open political contestation and instill a non-democratic belief in their citizens ${ }^{19}$.

Second, intra-mobility between citizens, especially in the framework of economic or socio-cultural exchange is very limited. As a result, the political regime in each country is still statically controlled by interests to perpetuate its political system such as in Indonesia, Malaysia, and Thailand. Every regime, whether it is dictatorial, authoritarian or democratic, maintains a pro-economic growth policy while at the same time, builds a political coalition that can make them strengthen their political domination longevity with the doctrine of economic progress in development ${ }^{20}$. Restrictions on civil society contribute to the uncertainty of the development model. Economic progress has become a panacea to pressure citizens that the political system is not something to be challenged or questioned as long as the government has succeeded in increasing the economic access of citizens. This factor has a significant influence on the next factor.

Third, economic domination by the ruling class had a variation in its composition according to their history and culture. General

\footnotetext{
${ }^{18}$ Dosch, Joern. "Vietnam in 2008: Foreign Policy

Successes but Daunting Domestic

Problems." Southeast Asian Affairs (2009): 373-

388.

${ }^{19}$ Chang, Alex, Yun-han Chu, and Bridget Welsh.

"Southeast Asia: Sources of regime support." Journal of Democracy 24, no. 2 (2013): 150-164.

${ }^{20}$ Rock, Michael T. Dictators, democrats, and development in Southeast Asia: Implications for the rest. Oxford University Press, 2017.
} 
conditions in this region show that the working class is weak because the industry is dominated by foreign ownership. The existence of an educated middle class as the backbone of democracy requires maturity concerning their access to the fulfillment of justice, freedom, and sovereignty. On the contrary, like in Malaysia, this region experienced economic progress but the middle class experienced an insecure syndrome. Poverty is reduced, but social inequality is increasing $^{21}$. In some countries, high levels of inequality have led to protests and political reforms, even though the scale has not moved to make strong democratic consolidation.

We had called the three factors above as "isolative factors," namely the factors that cause the wave of democratization does not work or else to experience a sudden stagnation because of specific and unique obstacles following the conditions and the typical regime in each country. The composition of the regime's support is also different. In the case of democratic regimes in Thailand, politicians collaborate with senior military officers and technocrats whereas in the Philippines, politicians are individual and bring their network technocrats when in power. The electoral political competition that promises democracy on a maximum scale cannot be guaranteed.

The democratic regime in this region is still lacking. Each country does not need to preserve their regional ties that potentially influence the conditions and the political stability of each respective country which result in low political awareness in general ${ }^{22}$.

\footnotetext{
${ }^{21}$ Embong, Abdul. State-led modernization and the new middle class in Malaysia. Springer, 2002.

Jomo, K. S. "Growth with equity in East

Asia." Southeast Asian paper tigers (2003): 196219.

${ }^{22}$ Aminuddin, M. Faishal, and Joko Purnomo. "Redefining ASEAN Way: Democratization and Intergovernmental Relations in Southeast Asia" Journal of ASEAN Studies 5, no. 1 (2017): 23-36.
}

Although, the record of socio-economic development in some countries is impressive but it is still based on the logic of productivity where social services are measured to what extent their contribution to economic development. It is also used to overcome various problems that arise in economic processes and social development. It has not moved to strengthen political participation in presenting stronger democratic regimes.

Moreover, autocratic and authoritarian regime survives within lower political participation regardless of the degree of level of education, as is shown in Singapore, Malaysia, Laos, and Vietnam. Hence, we can argue that the survival of the non-democratic regime is facilitated by the incidence of the low level of political participation. In this region, high levels of political participation are listed by Indonesia and the Philippines with a scale above seven while other countries are below 5 (BTI, 2018). The data of political participation also confirms that political transformation into a democratic regime may appear if the political participation is still at a high level. What is worrying is the fact that there is a declining trend on participation level in overall. There is a declining trend of political participation shown in Vietnam, Thailand, Laos, and Cambodia in recent years. If this trend is continuing, then it is tough to expect democracy breeds in this region. Level of trust in the election is more important to boost political participation rather than the level of education. Although the growth of well-educated people is significant, it does not accelerate the level of political participation. The increase in election trust, however, positively produces high and sustain political participation.

\section{Conclusion}

In the entire region, SEA gains positive benefits from economic liberalization but less convincing on political transformation. The continuing progress in economic development, unfortunately, was not followed by the shift from autocracy or 
authoritarian to a democratic regime. The high level of economic performance combined with stable political dynamic, however, are factors contributed to the survival of the autocratic and authoritarian regime. Based on socio-economic performance and political dynamic it is hard to find a healthy relationship between development and democratization. Our findings show a minor correlation between an increase in trends in human developments and a political change in a more democratic country. Moreover, economic development provides an insignificant foundation for the establishment of democracy. Further research on the type of economic policy chosen by every country and its impact on political transformation is needed to find the missing link between economic performance and political change.

The stability of democratization, however, seems to be influenced by the continuing progress in economic development. In recent political dynamic in Indonesia and Philippine, two countries who relatively success to institutionalizing democracy than others, there is a decline in

\section{REFERENCES}

Almond, G., \& Verba, S. (1963). The Civic Culture, Boston: Little, Brown

Aminuddin, M. F., \& Purnomo, J. (2017). Redefining ASEAN Way: Assesing Normative Foundation on Inter-governmental Relationship in Southeast Asia. Journal of ASEAN Studies, 5(1), 23-36.

Aspinall, E., \& Mietzner, M. (Eds.). (2010). Problems of democratisation in Indonesia: elections, institutions and society. Institute of Southeast Asian Studies.

Besley, T., \& Kudamatsu, M. (2006). Health and democracy. American Economic Review, 96(2), 313-318. the quality of democracy when the global economic crisis reduces economic progress. Hence, a significant decline in economic performance potentially harms the stability of democratization, and it may lead to the incidence of illiberal democracy.

Besides, it is clear that the fluctuations of the political regime are not always positively correlated with the development of democratic politics in South East Asia. Discontinuation of democratization take place in South East Asia due to "isolative factors" namely: (1) regional cooperation such as ASEAN does not provide space for reciprocal interventions between countries; (2) intra-mobility between citizens, especially in the framework of economic or socio-cultural exchange is very limited resulted in continuing control on political life done by old-established economic actors; (3) economic domination by the ruling class whose had variation in composition according to their own history and culture. Hence, a political disconnection is a key to understand the dynamics of political transformation in Southeast Asia.

Case, W. (2013). Politics in Southeast Asia: democracy or less. Routledge.

Carothers, T. (2002). The end of the transition paradigm. Journal of democracy, 13(1), 5-21.

Chambers, P., \& Croissant, A. (Eds.). (2010). Democracy under Stress: Civil-Military Relations in South and Southeast Asia. Silkworm Books.

Chang, A., Chu, Y. H., \& Welsh, B. (2013). Southeast Asia: Sources of regime support. Journal of Democracy, 24(2), 150-164.

Cheibub, J. A., \& Vreeland, J. R. (2008). Economic Development, Democratization and Democracy. American Economic Review, 98, 808-42. 
Dahl, Robert A, (1973), Polyarchy: Participation and Opposition, Yale University Press

Doorenspleet, R. (2019). Democracy and Development. In Rethinking the Value of Democracy (pp. 201-236). Palgrave Macmillan, Cham.

Dosch, Jörn. 'Vietnam in 2008: Foreign Policy Successes but Daunting Domestic Problems'. In Daljit Singh (ed) Southeast Asian Affairs 2009, Singapore: ISEAS 2010, pp. 373-388.

Embong, A. (2002). State-led modernization and the new middle class in Malaysia. Springer.

IMF. (2016).Regional Economic Outlook. Asia and Pacific. Washington DC (available online: https://www.imf.org/en/Publications/REO/AP AC/Issues/2017/03/06/Building-on-Asia-sStrengths-during-Turbulent-Times)

Jayasuriya, K., \& Rodan, G. (2007). Beyond hybrid regimes: more participation, less contestation in Southeast Asia. Democratization, 14(5), 773-794.

Jomo, K. S. (Ed.). (2003). Southeast Asian Paper Tigers?. Routledge.

Laothamatas, A. (Ed.). (1997). Democratization in Southeast and East Asia (Vol. 76). Institute of Southeast Asian Studies.

Lipset, S. M., \& Lakin, J. M. (2004). The democratic century (Vol. 9). University of Oklahoma Press.

Marwah, K, Tavakoli, A (2004). The effect of Foreign Capital and Imports on Economic Growth: Further Evidence from Four Asean Countries (1970-1998). Journal of Asean Economic, 5, 399-413
Neher, C. (2018). Democracy and development in Southeast Asia: the winds of change. Routledge.

Papaioannou, E., \& Siourounis, G. (2008). Economic and social factors driving the third wave of democratization. Journal of comparative Economics, 36(3), 365-387.

Polity IV, (2017), Polity IV Project, Political Regime Characteristics and Transitions, 18002017, http://www.systemicpeace.org/inscrdata.html>. Accessed on 05.10.2018

Przeworski, A., Alvarez, M. E., Cheibub, J. A., \& Limongi, F. (2000). Democracy and development: political institutions and wellbeing in the world, 1950-1990 (Vol. 3). Cambridge University Press.

Putzel, J. (1999). Survival of an imperfect democracy in the Philippines. Democratization, 6(1), 198-223.

Raquiza, A. R. (2012). State structure, policy formation, and economic development in Southeast Asia: The political economy of Thailand and the Philippines. Routledge.

Rock, M. T. (2017). Dictators, democrats, and development in Southeast Asia: Implications for the rest. Oxford University Press.

Rodan, G., \& Jayasuriya, K. (2007). The technocratic politics of administrative participation: case studies of Singapore and Vietnam. Democratization, 14(5), 795-815.

Schumpeter, J. A. (1942). Socialism, capitalism and democracy. Harper and Brothers.

Sidel, J. T. (2008). Social origins of dictatorship and democracy revisited: colonial state and Chinese immigrant in the making of modern Southeast Asia. Comparative Politics, 40(2), 127-147. 
Sirowy, L., \& Inkeles, A. (1990). The effects of democracy on economic growth and inequality: A review. Studies in Comparative International Development, 25(1), 126-157.

Slater, D. (2006). The Architecture of Authoritarianism Southeast Asia and the Regeneration of Democratization Theory. Taiwan Journal of Democracy, 2(2), 1-22.

Slater, D. (2009). Revolutions, crackdowns, and quiescence: Communal elites and democratic mobilization in Southeast Asia. American Journal of Sociology, 115(1), 203254.

Suri, T., Boozer, M. A., Ranis, G., \& Stewart, F. (2011). Paths to success: The relationship between human development and economic growth. World Development, 39(4), 506-522.

UNDP, (2017), Human Development Report, < http://hdr.undp.org/en/data> Accessed on 10.10.2018

World Bank, (1999), Does Democracy Facilitate the Economic Transition? An Empirical Study of Central and Eastern Europe and the Former Soviet Union. Policy Research Working Paper, 2194

BTI, (2015), Bertellsman Transformation Index, < https://www.bti-project.org/en/data/>. Accessed on 15.10.2018 